\title{
Soil Fertility Comparison between Rotations of Tobacco-Rice (TR) and Rape-Rice (RR)
}

\author{
Xiangzhen Kong1,2, Yansong $\mathrm{Xiao}^{3 *}$, Qinyi Zhi' ${ }^{4}$, Yahua $\mathrm{Liao}^{5}$, Bin $\mathrm{He}^{3}$, Hong Jian ${ }^{3}$, Juan $\mathrm{Li}^{3}$, \\ Zhihui Cao ${ }^{3}$, Sijun $\mathrm{Li}^{3}$, Decheng Li ${ }^{1}$
}

\author{
${ }^{1}$ Institute of Soil Science, Chinese Academy of Sciences, Nanjing, China \\ ${ }^{2}$ University of Chinese Academy of Sciences, Beijing, China \\ ${ }^{3}$ Chenzhou Tobacco Company of Hunan Province, Chenzhou, China \\ ${ }^{4}$ Hunan Tobacco Leaf Redrying Co. Ltd., Chenzhou, China \\ ${ }^{5}$ Hunan Provincial Company of CNTC, Changsha, China \\ Email: kongxiangzhen@issas.ac.cn, ^xiaoyansong106@126.com
}

How to cite this paper: Kong, X.Z., Xiao, Y.S., Zhi, Q.Y., Liao, Y.H., He, B., Jian, H., Li, J., Cao, Z.H., Li, S.J. and Li, D.C. (2021) Soil Fertility Comparison between Rotations of Tobacco-Rice (TR) and Rape-Rice (RR). Agricultural Sciences, 12, 1527-1537. https://doi.org/10.4236/as.2021.1212097

Received: November 16, 2021

Accepted: December 21, 2021

Published: December 24, 2021

Copyright $\odot 2021$ by author(s) and Scientific Research Publishing Inc. This work is licensed under the Creative Commons Attribution-NonCommercial International License (CC BY-NC 4.0). http://creativecommons.org/licenses/by-nc/4.0/ c) (1) () Open Access

\begin{abstract}
Tobacco-planting plays an important role in ensuring the high-quality tobacco raw materials supply and the local social and economic development in Chenzhou City. In recent years whether tobacco-planting is better for the maintenance and improvement of soil fertility than other crop-planting has been highly concerned. In this study, 16 soil fertility indicators and soil integrated index (IFI) were compared by 21 pairs of fields in Chenzhou city under the rotations of tobacco-rice (TF) and rice-rice (RR), and results showed that, comparing the mean values of soil fertility indicators, the contents of $\mathrm{OM}, \mathrm{TN}, \mathrm{AN}, \mathrm{AK}, \mathrm{S}$ and IFI were extremely significantly higher in TR than those in $\mathrm{RR}(\mathrm{p}<0.01)$, the contents of $\mathrm{Cu}, \mathrm{Ca}, \mathrm{Mg}$ and $\mathrm{Fe}$ were significantly higher in TR than those in RR ( $\mathrm{p}<0.05)$, but Mn content was significantly lower in TR than those in RR $(\mathrm{p}<0.05)$. Meanwhile the contents of TP, TK and $A P$ were insignificantly higher in $T R$ than those in $R R$, and the contents of $\mathrm{B}, \mathrm{Mo}$ and $\mathrm{Zn}$ were insignificantly lower in TR than those in RR. The above significant differences in soil fertility indicators were mainly due to relatively higher fertilizer inputs and less nutrient removal during tobacco-growing season than during rape-growing season, the net increase of $\mathrm{N}_{2} \mathrm{P}_{2} \mathrm{O}_{5}$ and $\mathrm{K}_{2} \mathrm{O}$ are $8.61,5.25$ and $24.89 \mathrm{~kg}$ per $667 \mathrm{~m}^{2}$ respectively in tobacco-growing season, while the net decrease of $\mathrm{N}, \mathrm{P}_{2} \mathrm{O}_{5}$ and $\mathrm{K}_{2} \mathrm{O}$ are $8.88,4.70$ and $4.62 \mathrm{~kg}$ per 667 $\mathrm{m}^{2}$ respectively in rape-growing season. C.V. of soil fertility indicators and IFI were meanly lower in TR (52.25\% and $15.95 \%$, respectively) than those in RR (63.07\% and $22.12 \%$, respectively). Comparatively, tobacco-planting can improve soil fertility better than rape-planting when rotated with late rice in Chenzhou city. For tobacco-planting, $\mathrm{Mg}$ fertilizer should be applied for $23.8 \%$ TR fields, while more $\mathrm{N}, \mathrm{K}, \mathrm{Ca}, \mathrm{Mg}, \mathrm{S}$ and $\mathrm{B}$ fertilizers should be ap-
\end{abstract}


plied for $42.86 \%, 23.81 \%, 14.29 \%, 47.62 \%, 80.95 \%$ and $47.62 \%$ RR fields, respectively.

\section{Keywords}

Comparison, Soil Fertility Indicator, Soil Integrated Index, Tobacco-Rice Rotation (TR), Rape-Rice Rotation (RR), Chenzhou

\section{Introduction}

Chenzhou city is located in the southeast of Hunan Province, between $112^{\circ} 13^{\prime}$ $114^{\circ} 14^{\prime}$ east longitude and $24^{\circ} 53^{\prime}-26^{\circ} 50^{\prime}$ north latitude with a total area of is $1.94 \times 10^{4} \mathrm{~km}^{2}$, which is belonged to the sub-tropical monsoon humid climate zone with annual sunshine duration of $1663 \mathrm{~h}$, temperature of $17.4^{\circ} \mathrm{C}$, precipitation of $1452 \mathrm{~mm}$ and frost-free period of $280 \mathrm{~d}$. With a long history of tobacco-planting as early as 1593 [1], Chenzhou is the most important and typical tobacco-planting region with burnt-pure sweet aroma in China [2], which plays an important role in ensuring the high-quality tobacco raw materials supply and the local social and economic development. The current area of the cultivated land in Chenzhou city is $22.0 \times 10^{4} \mathrm{hm}^{2}$ with the paddy field of $16.8 \times 10^{4} \mathrm{hm}^{2}$, and some paddy fields there are under the rotations of tobacco-rice (about $2.67 \times 10^{4}$ $\mathrm{hm}^{2}$ ) and rape-rice. In recent years, rotation is more beneficial to soil fertility maintenance and improvement has been highly concerned by the local agricultural decision-makers and farmers.

There are reports in China on the comparison of soil properties of tobacco fields under the different situations, which included soil nutrients [3] [4] [5] [6], enzyme activities, bacterial community structures and diversities [7] [8] [9]. However, fewer studies were conducted on the comparison of soil nutrients or fertilities between tobacco fields and other crop fields, for example, Long et al. [10] found that soil aggregates under maize continuous-cropping had higher organic carbon content, carbon sequestration capacity and contribution rates to soil organic carbon than tobacco continuous-cropping in northwestern Hunan. Zhang [11] showed no significant difference in soil organic matter, total nitrogen, total phosphorus, total potassium, alkali-hydrolyzable nitrogen, available sulfur and CEC between tobacco-rice rotation and rice-rice rotation in Jianghua, Changning, Xintian and Changsha of Hunan, but available phosphorus and potassium in the former were significantly higher than those in the latter. Wang et al. [12] disclosed that rice-rice rotation and tobacco-rice rotation were better for soil fertility improvement than the planting modes of single rice, Chinese medicinal materials, rice-rape and rice-wheat in Xuanzhou district of South Anhui.

Although some literatures were published about tobacco soil in Chenzhou city [13] [14] [15] [16], which play an important guiding role in improving soil fer- 
tility and quality of tobacco fields, so far there is no report on comparison of soil fertility indicators and integrated fertility indexes (IFI) under the rotations of tobacco-rice (TR) and rape-rice (RR). Therefore, this study was conducted to clarify the difference between TR and RR in maintaining or improving soil quality in order to provide further scientific guidance for fertilization and soil improvement.

\section{Methods and Materials}

\subsection{Soil Sampling and Determination}

In the December of 2020 after the later rice was harvested, 21 pairs of tight adjacent TR and RR fields were selected in Chenzhou city according to the spatial distribution tobacco fields (see Figure 1). Soil samples of the plough layers (0 $20 \mathrm{~cm}$ ) in the selected TR and RR fields were collected randomly at 8 sites and mixed fully (1.5 - $2 \mathrm{~kg}$ in total).

16 soil fertility indicators were selected in this study, and their determination methods are as follows: organic matter (OM) by potassium dichromate oxidation, total nitrogen (TN) by Kelvin method, available nitrogen (AN) by alkali-hydrolyzed diffusion, total and available phosphorus (TP and AP) by molybdenum antimony colorimetry, total and available potassium (TK and AK) by

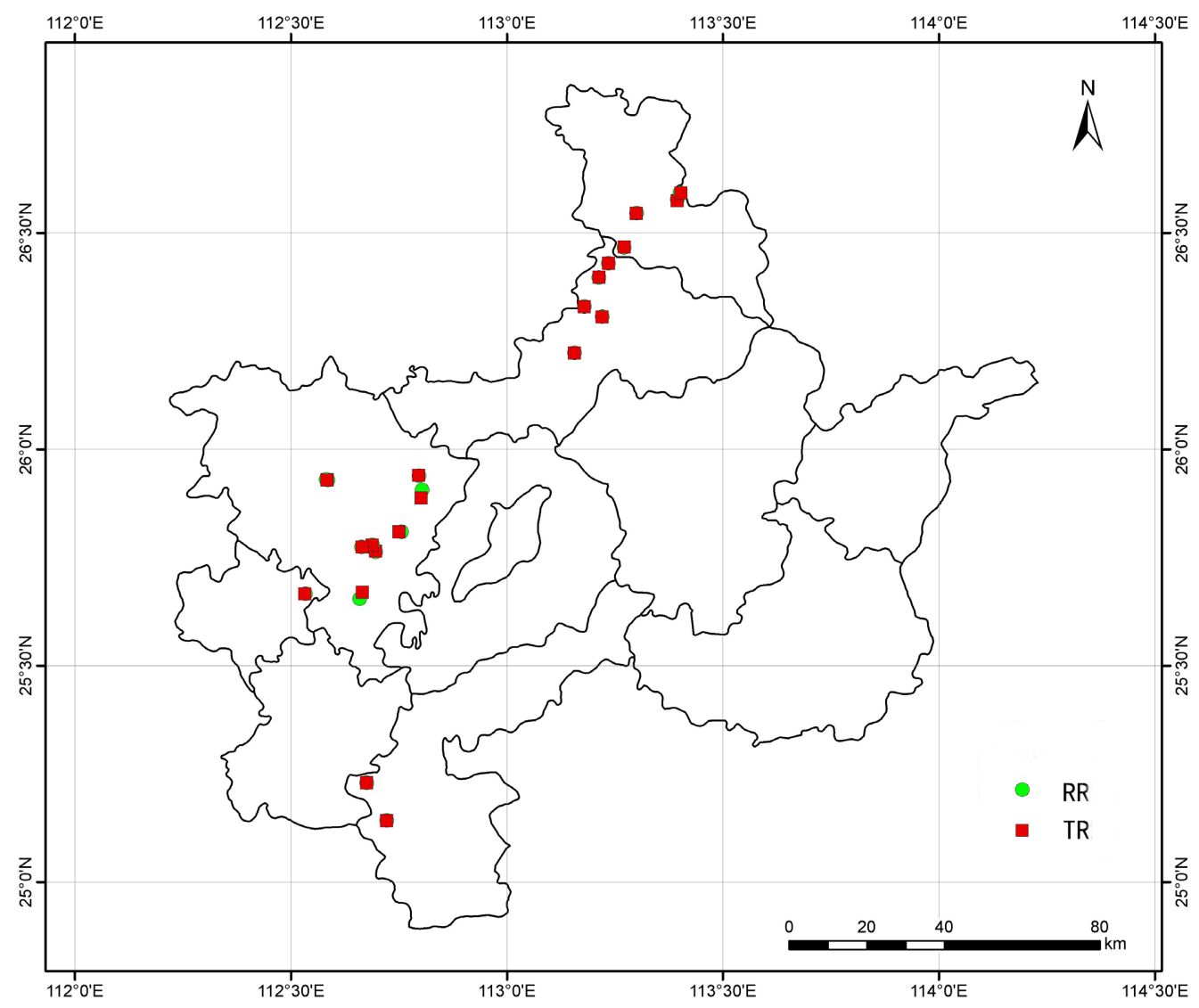

Figure 1. Sites of selected TR and RR fields in Chenzhou city. 
photometry, available calcium $(\mathrm{Ca})$, magnesium $(\mathrm{Mg})$, sulfur $(\mathrm{S})$, copper $(\mathrm{Cu})$, iron $(\mathrm{Fe})$, manganese $(\mathrm{Mn})$ and zinc $(\mathrm{Zn})$ by atomic absorption spectrophotometry, effective boron (B) by curcumin colorimetry, effective molybdenum (Mo) by polarization spectrometer. All the detailed determination methods for soil fertility indictors could be found in related literatures [17] [18].

\subsection{Soil Fertility Indicator Grading and Quantitative Assessment}

There are many reports available in China on the grading standards of soil fertility indicators for tobacco-planting fields. In this study, for easily and rapidly assess tobacco-planting suitability of the fertility indicators, all fertility indicators were simply divided into 3 grades (low, suitable, high) as in Table 1 based on the related literatures in Hunan Province and its neighboring areas [19] [20] [21] [22] [23].

There are various methods for the assessment of soil $I F I$ [24], usually soil $I F I$ is calculated according to the following formula $I F I=\Sigma\left(W_{i} \times N_{i}\right)$, where $W_{i}$ is for the weight of indicator $i$, according to a current concept of "storing nutrients in soil" and in order to simply calculate soil $I F$, in this study the contributions of all fertility indicators to soil IFI were thought as equal so the weight value of each fertility indicator was meanly defined as $1 / 16=0.0625 ; N_{i}$ is the membership of indicator $i$. which was simply calculated as the measured value $\left(X_{i}\right)$ of an indicator divided by the measured maximum value of that indicator $\left(X_{\max }\right)$. Thus, soil $I F I$ is also ranged from 0 to 1 , the higher $I F I$ value, the higher soil fertility.

Table 1. Grading standards of soil fertility indicators for tobacco-planting fields.

\begin{tabular}{cccc}
\hline \multirow{2}{*}{ Fertility indicator } & \multicolumn{3}{c}{ Grade } \\
\cline { 2 - 4 } OM & Low & Suitable & high \\
\hline $\mathrm{AN}$ & $<15$ & $15-30$ & $\geq 30$ \\
$\mathrm{AP}$ & $<100$ & $100-180$ & $\geq 180$ \\
$\mathrm{AK}$ & $<150$ & $150-220$ & $\geq 30$ \\
$\mathrm{Ca}$ & $<6$ & $6-10$ & $\geq 220$ \\
$\mathrm{Mg}$ & $<1.0$ & $1.0-1.6$ & $\geq 10$ \\
$\mathrm{~S}$ & $<16$ & $16-30$ & $\geq 1.6$ \\
$\mathrm{~B}$ & $<0.3$ & $0.3-0.6$ & $\geq 0.6$ \\
$\mathrm{Cu}$ & $<0.5$ & $0.5-1.0$ & $\geq 1.0$ \\
$\mathrm{Fe}$ & $<4.5$ & $4.5-10$ & $\geq 10$ \\
$\mathrm{Mn}$ & $<10$ & $10-20$ & $\geq 20$ \\
$\mathrm{Mo}$ & $<0.15$ & $0.15-0.2$ & $\geq 0.2$ \\
$\mathrm{Zn}$ & $<1.0$ & $1.0-2.0$ & $\geq 2.0$ \\
\hline $\mathrm{Con}$ & & 150 &
\end{tabular}

Note: in the first column, SOM, TN, TP and TK, g/kg; AN, AP, AK, S, B, Fe, Mn, Cu, Zn and $\mathrm{Mo}, \mathrm{mg} / \mathrm{kg} ; \mathrm{Ca}, \mathrm{cmol}\left(1 / 2 \mathrm{Ca}^{2+}\right) / \mathrm{kg} ; \mathrm{Mg}, \mathrm{cmol}\left(1 / 2 \mathrm{Mg}^{2+}\right) / \mathrm{kg}$. The same below. 


\subsection{Data Processing and Statistics}

Microsoft Excel 2016 and IBM Statistics SPSS 22.0 software were used for statistical analysis of the data, and T-test method of paired sample was used for the multiple comparisons [25].

\section{Results}

\subsection{Suitability Assessment of TR and RR Fields for Tobacco-Planting}

Table 2 lists the field numbers of TR and RR in the lower grades of soil fertility indicators for the suggestion of reasonable fertilization and soil improvement for tobacco planting, it can be seen that no field was lower in $\mathrm{OM}, \mathrm{Cu}, \mathrm{Fe}$ and $\mathrm{Zn}$ in TR and RR. For TR, only 1 field was lower in AN, AP and Mn, 2 fields were lower in $\mathrm{AK}, \mathrm{Ca}, \mathrm{S}, \mathrm{B}$ and Mo, while 5 fields were lower in $\mathrm{Mg}$. However, For RR, 1 field was lower in AP and Mo, 3 fields were lower in $\mathrm{Ca}, 5$ fields were lower in $\mathrm{AK}, 9$ fields were lower in AN, 10 fields were lower in $\mathrm{Mg}$ and B, 17 fields were lower in S. These above differences in field numbers show that TR are better than RR in soil fertility indicators, thus, it is better for the megafinance and improvement of soil fertility. For the reasonable application of fertilizers for tobacco-planting, $\mathrm{Mg}$ fertilizer should be applied for $23.8 \%$ TR fields, while more $\mathrm{N}$, $\mathrm{K}, \mathrm{Ca}, \mathrm{Mg}, \mathrm{S}$ and B fertilizers should be applied for $42.86 \%, 23.81 \%, 14.29 \%$, $47.62 \%, 80.95 \%$ and $47.62 \%$ RR fields, respectively.

\subsection{Statistics and Comparison of Soil Fertility Indicators between TR and RR}

Table 3 shows the general statistical results of soil fertility indicators of TR and

Table 2. Field numbers with low grades of soil fertility indicators.

\begin{tabular}{ccccc}
\hline \multirow{2}{*}{ Fertility indicator } & \multicolumn{2}{c}{ TR } & \multicolumn{2}{c}{ RR } \\
\cline { 2 - 5 } OM & Field no. & $\%$ & Field no. & $\%$ \\
AN & 0 & 0 & 0 & 0 \\
AP & 1 & 4.76 & 9 & 42.86 \\
AK & 1 & 4.76 & 1 & 4.76 \\
Ca & 2 & 9.52 & 5 & 23.81 \\
Mg & 2 & 9.52 & 3 & 14.29 \\
S & 5 & 23.81 & 10 & 47.62 \\
B & 2 & 9.52 & 17 & 80.95 \\
Cu & 2 & 9.52 & 10 & 47.62 \\
Fe & 0 & 0 & 0 & 0 \\
$\mathrm{Mn}$ & 0 & 0 & 0 & 0 \\
$\mathrm{Mo}$ & 1 & 4.76 & 0 & 0 \\
$\mathrm{Zn}$ & 2 & 9.52 & 1 & 4.76 \\
\hline
\end{tabular}


Table 3. Statistical descriptions of soil fertility indicators.

\begin{tabular}{|c|c|c|c|c|c|c|c|c|c|c|}
\hline \multirow{2}{*}{$\begin{array}{l}\text { Fertility } \\
\text { indictor }\end{array}$} & \multicolumn{2}{|c|}{ Min. } & \multicolumn{2}{|c|}{ Max. } & \multicolumn{2}{|c|}{ Mean \pm S.D. } & \multicolumn{2}{|c|}{ C.V. (\%) } & \multirow{2}{*}{$\begin{array}{c}\text { Difference } \\
(\%)\end{array}$} & \multirow{2}{*}{$\mathrm{p}$} \\
\hline & TR & $\mathrm{RR}$ & TR & $\mathrm{RR}$ & TR & $\mathrm{RR}$ & TR & $\mathrm{RR}$ & & \\
\hline $\mathrm{OM}$ & 20.30 & 17.30 & 56.10 & 51.20 & $39.59 \pm 9.55$ & $27.80 \pm 8.59$ & 24.13 & 30.90 & 42.39 & 0 \\
\hline $\mathrm{TN}$ & 1.20 & 0.89 & 2.96 & 2.81 & $2.09 \pm 0.48$ & $1.50 \pm 0.44$ & 22.92 & 29.25 & 39.20 & 0 \\
\hline $\mathrm{TP}$ & 0.59 & 0.47 & 1.52 & 1.57 & $1.01 \pm 0.26$ & $0.89 \pm 0.30$ & 26.03 & 33.86 & 13.68 & 0.095 \\
\hline $\mathrm{TK}$ & 6.83 & 6.15 & 20.98 & 22.38 & $12.44 \pm 3.78$ & $12.02 \pm 3.97$ & 30.39 & 33.04 & 3.46 & 0.669 \\
\hline AN & 92.00 & 74.00 & 202.00 & 173.00 & $143.19 \pm 27.98$ & $109.19 \pm 27.83$ & 19.54 & 25.48 & 31.14 & 0.001 \\
\hline $\mathrm{AP}$ & 14.60 & 13.50 & 72.20 & 82.50 & $42.60 \pm 15.90$ & $37.85 \pm 17.57$ & 37.32 & 46.41 & 12.57 & 0.230 \\
\hline $\mathrm{AK}$ & 106.0 & 75.0 & 418.00 & 455.0 & $279.4 \pm 84.9$ & $206.7 \pm 30.8$ & 30.37 & 43.44 & 35.18 & 0.009 \\
\hline $\mathrm{Ca}$ & 4.39 & 3.47 & 48.73 & 50.06 & $24.72 \pm 17.31$ & $14.08 \pm 11.56$ & 70.02 & 82.07 & 75.54 & 0.038 \\
\hline $\mathrm{Mg}$ & 0.54 & 0.63 & 2.72 & 2.63 & $1.71 \pm 0.67$ & $1.24 \pm 0.55$ & 38.94 & 44.21 & 38.18 & 0.013 \\
\hline S & 14.12 & 0.78 & 50.32 & 49.01 & $30.35 \pm 11.18$ & $10.44 \pm 11.58$ & 36.83 & 110.92 & 190.61 & 0 \\
\hline B & 0.25 & 0.17 & 0.68 & 3.58 & $0.48 \pm 0.12$ & $0.51 \pm 0.72$ & 25.07 & 142.82 & -4.60 & 0.926 \\
\hline $\mathrm{Cu}$ & 1.92 & 1.26 & 8.15 & 7.70 & $4.60 \pm 1.72$ & $3.24 \pm 1.61$ & 37.32 & 49.70 & 41.96 & 0.018 \\
\hline $\mathrm{Fe}$ & 45.76 & 20.60 & 171.60 & 246.25 & $97.25 \pm 42.54$ & $68.98 \pm 53.28$ & 43.75 & 77.25 & 40.99 & 0.049 \\
\hline $\mathrm{Mn}$ & 8.50 & 13.70 & 19.53 & 19.35 & $16.21 \pm 2.97$ & $17.72 \pm 1.59$ & 18.35 & 8.96 & -8.50 & 0.017 \\
\hline Mo & 0.08 & 0.08 & 7.56 & 9.58 & $1.20 \pm 2.16$ & $1.36 \pm 2.09$ & 179.73 & 153.96 & -11.60 & 0.811 \\
\hline $\mathrm{Zn}$ & 1.35 & 1.56 & 21.46 & 13.34 & $4.55 \pm 4.63$ & $4.85 \pm 2.91$ & 101.64 & 59.99 & -6.08 & 0.822 \\
\hline
\end{tabular}

Note: data in Difference column were calculated as: $(T R-R R) \times 100 / R R$.

RR. Comparing the mean values of soil fertility indicators, it can be seen that the contents of OM, TN, AN, AK and S were extremely significantly higher in TR than those in $\mathrm{RR}$, the contents of $\mathrm{Cu}, \mathrm{Ca}, \mathrm{Mg}$ and Fe were significantly higher in TR than those in RR. Meanwhile, the contents of TP, TK and AP were insignificantly higher in TR than those in RR. Only Mn content was significantly lower in TR than those in RR, meanwhile the contents of B, Mo and Zn were insignificantly lower in TR than those in RR. It also can be found from Table 3 that C.V. of soil fertility indicators were ranged from $18.35 \%$ to $179.73 \%$ for TR and $8.96 \%$ to $153.96 \%$ for RR, but the mean value of C.V. was $46.40 \%$ for TR, which was lower than that of RR $(60.76 \%)$.

\subsection{Statistics and Comparison of IFI in Chenzhou TR and RR}

Table 4 exhibits the statistic information of soil IFI of TR and RR, it can be seen that soil IFI was ranged from $0.336-0.723$ with a mean of 0.528 for TR, which is significantly higher than that of RR (ranged from $0.287-0.653$ with a mean of $0.412, \mathrm{p}<0.001)$. For the $21 \mathrm{RR}$ fields, there were 10,10 and 1 fields with soil IFI in the range of $0.2-0.4,0.4-0.6$ and $0.6-0.8$ respectively, while for the $21 \mathrm{RR}$ fields, there were 1,16 and 4 fields with soil IFI in the range of $0.2-0.4,0.4-0.6$ and $0.6-0.8$ respectively. It also can be found from Table 4 that C.V. of soil IFI were $15.95 \%$ for TR, which is lower than RR (22.12\%). 
Table 4. Statistic descriptions of soil IFI of TR and RR.

\begin{tabular}{ccccc}
\hline Rotation mode & Min. & Max. & Mean \pm S.D. & C.V. (\%) \\
\hline TR & 0.336 & 0.723 & $0.528 \pm 0.084 \mathrm{~A}$ & 15.95 \\
RR & 0.287 & 0.653 & $0.412 \pm 0.091 \mathrm{~B}$ & 22.12 \\
\hline
\end{tabular}

Note: values in the same column followed by different uppercase letters are significantly different at the 0.001 level.

\section{Discussion}

Soil fertility assessment is one of the basic studies in soil science, and it is also important for the maintenance and improvement of soil fertility, new literatures are continuously published even in recent years [26] [27] [28] [29]. Meanwhile, soil fertility evaluation of tobacco-planting fields also has been reported more so far [19] [20] [21] [22] [23], but fewer studies compared the differences in soil fertility between TR and RR, our study gives the preliminary information on this issue, and proved that TR is better for the megafinance and improvement of soil fertility than RR, which is similar as the results obtained by Wang et al. [6].

For the differences in the contents of OM and effective nutrients between TR and RR, according to our survey in Chenzhou city, the straws of flue-cured tobacco, rape and rice are all returned to the fields. Here, the nutrient contents input from fertilizers into soil and removal out from soil by rice yield are not considered in this study (generally $15 \mathrm{~kg}$ compound fertilizer $\left(\mathrm{N}_{2} \mathrm{P}_{2} \mathrm{O}_{5}: \mathrm{K}_{2} \mathrm{O}=\right.$ $15: 15: 15)+5 \mathrm{~kg}$ urea $(46.2 \% \mathrm{~N})$, rice yield is about $700 \mathrm{~kg})$. The fertilizers applied in tobacco season included $15 \mathrm{~kg}$ cake fertilizer, $50 \mathrm{~kg}$ base fertilizer, $8 \mathrm{~kg}$ seedling raising fertilizer, $50 \mathrm{~kg}$ topdressing fertilizer and $15 \mathrm{~kg}$ potassium sulfate, the total inputs of $\mathrm{N}, \mathrm{P}_{2} \mathrm{O}_{5}$ and $\mathrm{K}_{2} \mathrm{O}$ are about 1.15, 9.23 and $27.61 \mathrm{~kg} 667$ $\mathrm{m}^{2}$, respectively; while the total $\mathrm{N}, \mathrm{P}_{2} \mathrm{O}_{5}$ and $\mathrm{K}_{2} \mathrm{O}$ removed out by tobacco leaves (the yield is about $150 \mathrm{~kg} 667 \mathrm{~m}^{2}$ ) are about $2.54,3.98$ and $2.72 \mathrm{~kg} 667 \mathrm{~m}^{2}$, respectively; Thus, the net increase of $\mathrm{N}_{2} \mathrm{P}_{2} \mathrm{O}_{5}$ and $\mathrm{K}_{2} \mathrm{O}$ are about 8.61, 5.25 and $24.89 \mathrm{~kg} 667 \mathrm{~m}^{2}$, respectively. In addition, the organic matter input was $8 \mathrm{~kg} 667$ $\mathrm{m}^{2}$ by applying cake fertilizer. The fertilizers applied in rape season were $30 \mathrm{~kg}$ compound fertilizer and $10 \mathrm{~kg}$ urea, the total inputs of $\mathrm{N}, \mathrm{P}_{2} \mathrm{O}_{5}$ and $\mathrm{K}_{2} \mathrm{O}$ are about 9.12, 4.50 and $4.50 \mathrm{~kg} 667 \mathrm{~m}^{2}$, respectively; while the total $\mathrm{N}, \mathrm{P}_{2} \mathrm{O}_{5}$ and $\mathrm{K}_{2} \mathrm{O}$ removed out by rapeseed (the yield is about $400 \mathrm{~kg} 667 \mathrm{~m}^{2}$ ) are about 18.00 , 9.20 and $9.12 \mathrm{~kg} 667 \mathrm{~m}^{2}$, respectively; Thus, the net decrease of $\mathrm{N}_{2} \mathrm{P}_{2} \mathrm{O}_{5}$ and $\mathrm{K}_{2} \mathrm{O}$ are about $8.88,4.70$ and $4.62 \mathrm{~kg} 667 \mathrm{~m}^{2}$, respectively. Therefore, it could be thought that soil fertility is improved in tobacco season but is deteriorated in rape season. These above data could explain why soil OM, AN and AK of TR were significantly higher than those of RR (for AP, TR was also higher than RR, although no significant level is obtained.

$\mathrm{Ca}$ and Mg was significantly higher in TR than in RR, which could be related with that phosphorus in tobacco compound fertilizers applied in Chenzhou comes from calcium magnesium phosphate, and sometimes the applied dolomite powders rich in $\mathrm{Ca}$ and $\mathrm{Mg}$ to improve the acid tobacco fields $(\mathrm{pH}<5.5)$. 
the significant higher of $S$ in TR than in RR could be attributed to the application of potassium sulphate, which is the most important and necessary topdressing (usually $225 \mathrm{~kg} \mathrm{hm}^{2}$ ) in China for the growth of high-quality tobacco [30]. However, it should be noticed that the application of potassium sulphate should be strictly monitored and controlled because excessive $S$ would worsen the quality of tobacco leaves [31] [32]. It needs further to explore the significant higher of $\mathrm{Cu}$ and $\mathrm{Fe}$ in TR than RR, one reason may be the application of the pesticides containing $\mathrm{Cu}$ or $\mathrm{Fe}$. No significant difference in $\mathrm{B}$, Mo and $\mathrm{Zn}$ between TR and RR may be related with little concern were paid on these trace nutrients, thus, the corresponding fertilizers are seldomly used, meanwhile there are few literatures on the application of these fertilizers for tobacco-planting in China [33] [34] [35] [36].

Soil fertility affects or determines the growth, yield and quality of tobacco, it also determines the economic benefits of local tobacco-planting farmers, comparatively, the net income of tobacco-planting (about 1000 - 2000 yuan) is higher than that of rape-planting (about 200 yuan), so more and great concerns have been paid to soil improvement, almost all the tobacco-planting regions in China have formulated the technical regulation of tobacco planting, which can homogenize soil fertility of tobacco fields, so the mean values of C.V. of soil fertility indicators and IFI were lower in TR (46.40\% and $15.95 \%$, respectively) than those in RR (60.76\% and $22.12 \%$, respectively, see Table 2 and Table 3$)$.

It should be pointed that there are certain relationships between soil fertility with the growth, yield and quality of tobacco, however, it is not studied in this study but would be conducted in our further research.

\section{Conclusion}

This study compared soil fertility indicators and integrated fertility index (IFI) under the rotations of tobacco-rice (TR) and rape-rice (RR) in Chenzhou city, comparatively, TR was significantly higher than RR in soil OM, TN, AN, AK, $\mathrm{Ca}, \mathrm{Mg}, \mathrm{S}, \mathrm{Cu}, \mathrm{Fe}$ and $I F I$, but $\mathrm{Mn}$ was significantly lower in TR than RR, while there was no significant difference in the contents of soil TP, TK, AP, B, Mo and $\mathrm{Zn}$. The above significant differences could be attributed due to the higher fertilizer inputs and less nutrient removal during tobacco-growing season than during rape-growing season, which proves that tobacco-planting can improve soil fertility better than rape-planting when rotated with late rice in Chenzhou city.

\section{Acknowledgements}

This study was supported by the Project of Chenzhou Company of Hunan Tobacco Company (No. 2019-45). We would like to express thanks to those for soil sampling and analysis.

\section{Conflicts of Interest}

The authors declare no conflicts of interest regarding the publication of this paper. 


\section{References}

[1] Editorial Committee of Tobacco Annals of Chenzhou City (2005) Tobacco Annals of Chenzhou City. Hunan People's Publishing House, Changsha. (In Chinese)

[2] Luo, D.S., Wang, B. and Qiao, X.Y. (2019) Explanation of National Regionalization of Leaves Style of Flue-Cured Tobacco. Acta Tabacaria Sinica, 25, 1-9. (In Chinese)

[3] Gao, L., Lin, C.H., Chen, X.Y., et al. (2019) Comparative Study on Soil Nutrient Characteristics of Regions with Tobaccos of Different Scents in Nanxiong of Guangdong. Guangdong Agricultural Science, 46, 50-57. (In Chinese)

[4] $\mathrm{Mu}, \mathrm{Z}$. (2013) Comparative Study of Rare Earth Elements Content and Main Chemical Indexes of Soil between Clean Aroma Type Tobacco Region and Full Aroma Type Tobacco Region. Master's Thesis, Chinese Academy of Agricultural Sciences, Beijing. (In Chinese)

[5] Luo, W.B., Xiang, P.H. and Yang, Y.C. (2009) Comparison of the Fertility Status of Different Soil Types in Qidong Tobacco-Growing Areas of Hunan Province. Journal of Shaoyang University (Natural Science Edition), 6, 57-60. (In Chinese)

[6] Wang, L., Chu, J.Y., Bi, Q.W., et al. (2008) Comparison on Several Contents of Soil Nutrient in Liuyang Tobacco-Growing Areas. Modern Agricultural Sciences, 15, 40-43. (In Chinese)

[7] Zhang, S.T., Chen, X.Y., Yang, Q.M., et al. (2017) Comparison of Bacterial Diversity of Paddy-Tobacco Rotation Soil in Sanming. Chinese Agricultural Science Bulletin, 33, 85-90. (In Chinese)

[8] Shi, P.Y., Yang, C.C., Jia. M., et al. (2020) Comparison of Soil Enzyme Activity and Bacterial Community Structure in Tobacco-Growing Rhizosphere under Different Incidence of Black Tibia Disease. Soils and Fertilizers Sciences in China, No. 1, 178-187. (In Chinese)

[9] Jia, Z.H., Yi, J.H., Su, R.Y., et al. (2011) Comparison of Soil Bacterial Diversity in Rotation and Monocropping Soil in Tobacco Growing Area in Yuxi, Yunnan, China. Chinese Journal of Applied and Environmental Biology, 17, 162-168. (In Chinese) https://doi.org/10.3724/SP.J.1145.2011.00162

[10] Long, S.P., Liao, C.L., Chen, S., et al. (2021) Comparison of Organic Carbon Characteristics in Soil Aggregates of Maize and Tobacco Continuous Cropping Fields in Northwestern Hunan. Chinese Tobacco Science, 42, 44-49. (In Chinese)

[11] Zhang, H. (2016) The Comparison of Some Soil Nutrition Indices of the Tobacco-Rice Rotation Soils and Rice-Rice Rotation Soils. Master's Thesis, Hunan Agricultural University, Changsha. (In Chinese)

[12] Wang, A.Q., Yang, P., Zhao, Y.Z., et al. (2021) Current Topsoil Fertility of Farmlands under Different Planting Patterns-A Case Study of Xuanzhou District of South Anhui. Soils, 53, 277-284. (In Chinese)

[13] Kuang, C.F., Zhou, G.S., Deng, Z.P., et al. (2000) Soil Nutrient Status in Chenzhou Tobacco Planting Areas. Acta Tabacaria Sinica, 31, 33-37. (In Chinese)

[14] Guo, T., Li, H.G., Li, W., et al. (2019) Spatial-Temporal Variability and Factors to Influence Boron Availability in Tobacco-Planting Soils of Rotating Paddy-Upland Fields in Southern Hunan. Tobacco Science and Technology, 52, 27-34. (In Chinese)

[15] Li, Q., Yan, C.B., Liu, Y.J., et al. (2019) Preliminary Study on Spatial Distribution and Influencing Factors of Tobacco-Growing Soil pH in Chenzhou. Acta Tabacaria Sinica, 25, 50-58. (In Chinese) 
[16] Gao, X., Zhou, L.K., Guo, T., et al. (2020) Spatial and Temporal Variability of Soil Organic Matter and Total Nitrogen and Influencing Factors in Chenzhou Tobacco-Growing Area, Hunan Province. China Journal of Soil Science, 51, 686-693. (In Chinese)

[17] Bao, S.D. (2000) Soil Agrochemical Analysis. Third Edition, China Agriculture Press, Beijing. (In Chinese)

[18] Lu, R.K. (2000) Methods for Agricultural Chemical Analysis of Soils. China Agricultural Science and Technology Press, Beijing. (In Chinese)

[19] Liu, J.X., Liu, X.H. and Chen, C.Q. (2009) Analysis and Comprehensive Evaluation of Soil Fertility Status for Tobacco-Growing Areas in the North-West of Hunan Province. Chinese Agricultural Science Bulletin, 25, 46-50. (In Chinese)

[20] Duan, S.H., Liu, T.B., Li, J.Y. and Zhou, Z.C. (2017) Evaluation of Soil Fertility and Variability of Nutrient Contents of Tobacco Growing Areas of Liuyang County of Hunan, China. China Tobacco Science, 38, 33-38. (In Chinese)

[21] Liang, H. (2014) Evaluation of Soil Fertility Status for Tobacco Growing Area in Chongqing. Master's Thesis, Southwest University, Chongqing. (In Chinese)

[22] Xiao, Y., Gao, J., Li, B., et al. (2020) Characteristics and Correlation Analysis of Soil Nutrients in Plow Layer of Different Tobacco Planting Areas in Sichuan. Chinese Tobacco Science, 41, 37-43. (In Chinese)

[23] Chen, J. and Tang, Y.J. (2006) Analysis on Soil Fertility of Main District Planting Flue-Cured Tobacco in Guizhou. Chinese Agricultural Science Bulletin, 22, 356-359.

[24] Lin, K., Li, D.C. and Zhang, G.L. (2017) Literature Analysis on Soil Quality Assessment in China Based on CNKI Database. China Journal of Soil Science, 48, 736-744. (In Chinese)

[25] Yu, J.H. and He, X.H. (2003) Data Statistical Analysis and SPSS Applications. Posts \& Telecommunications Press, Beijing.

[26] Tongkoom, K., Marohn, C., Piepho, H.P., et al. (2021) Combining Farmers' and Scientists' Tree Species and Soil Fertility Assessment for Improved Cropping Decisions in Swidden Systems of Northern Thailand. Ecological Indicators, 127, Article ID: 107719. https://doi.org/10.1016/j.ecolind.2021.107719

[27] Wang, Z.G., Wang, G.C., Ren, T.Y., et al. (2021) Assessment of Soil Fertility Degradation Affected by Mining Disturbance and Land Use in a Coalfield via Machine Learning. Ecological Indicators, 125, Article ID: 107608. https://doi.org/10.1016/j.ecolind.2021.107608

[28] Wang, Y.X., Liu, G.H., Zhao, Z.H., et al. (2021) Assessment of Coastal Soil Fertility Based on Environmental Impact: A Case Study in the Yellow River Delta, China. Journal of Coastal Conservation, 25, Article ID: 35. https://doi.org/10.1007/s11852-021-00823-6

[29] Chen, J., Qu, M.K., Zhang, J.L., et al. (2021) Soil Fertility Quality Assessment Based on Geographically Weighted Principal Component Analysis (GWPCA) in Large-Scale Areas. Catena, 201, Article ID: 105197. https://doi.org/10.1016/j.catena.2021.105197

[30] Song, X.P., Song, W.J., Lu, W.L., et al. (2019) Effects of Different Potassium Sulfate Levels on Bacterial Community of Tobacco Planting Soil. Chinese Tobacco Science, 40, 33-44. (In Chinese)

[31] Wang, X.D., Xu, Z.C., Xie, Y., et al. (2018) Suitable Soil Available Sulfur and Tobacco Leaf Sulfur Contents for High Quality Tobacco Production in Qujing Area, Yunnan Province. Journal of Plant Nutrition, 24, 528-534. (In Chinese) 
[32] Zhang, J.G., Luang, H.B., Shen, G.M., et al. (2013) Effects of Successive Fertilization of Potassium Sulfate on Change of Sulfur Content in Soil and Tobacco Plant. Chinese Tobacco Science, 34, 77-82. (In Chinese)

[33] Lv, D.S. (2013) Study on the Effects of Boron, Zinc and Molybdenum Nutrition in Flue-Cured Tobacco Fields. Master' Thesis, Hunan Agricultural University, Changsha. (In Chinese).

[34] Chen, L.J., Shen, H., Liu, X.Y., et al. (2013) Effects of Different Magnesium, Zinc and Boron Levels on Yield and Quality of Flue-Cured Tobacco in Tengchong Volcanic Ash Soil. Journal of Hunan Agricultural University, 39, 591-596. (In Chinese) https://doi.org/10.3724/SP.J.1238.2013.00591

[35] Tan, J., Liu, X.Y., Li, Q., et al. (2017) Distribution of Available Zinc in Tobacco-Planting Soils in Wenshan and Its Influential Factors. Soils, 49, 719-724. (In Chinese)

[36] Zhan, H., Zhang, Y.J., Zhang, Z.J., et al. (2018) Study on the Available Zine Contents and Appropriate Amount of Zinc Fertilizer in Panzhihua. Journal of Anhui Agricultural Sciences, 46, 113-116, 158. (In Chinese) 